\title{
Power Management Strategy in PV-Wind Hybrid System with Cuckoo Search
}

\author{
Ch. Prem Prakash ${ }^{1}$ | Kundeti Krishna Rao ${ }^{2}$ \\ ${ }^{1}$ PG Student, Dept of EEE, Vikas College of Engineering, Vijayawada, India \\ ${ }^{2}$ Assistant Professor, Dept of EEE, Vikas College of Engineering, Vijayawada, India
}

To Cite this Article

Ch. Prem Prakash and Kundeti Krishna Rao, "Power Management Strategy in PV-Wind Hybrid System with Cuckoo Search", International Journal for Modern Trends in Science and Technology, Vol. 06, Issue 07, July 2020, pp.:143-147; https://doi.org/10.46501/IJMTST060723

\section{Article Info}

Received on 17-June-2020, Revised on 28-June-2020, Accepted on 15-July-2020, Published on 22-July-2020.

\section{ABSTRACT}

The main theme of this paper is to propose a Cuckoo MPPT technique for Hybrid PV-Wind Smart grid system. Generally, Smart grid is an electrical grid which includes a variety of operation and energy measures including smart appliances, renewable energy resources, and energy efficient resources. Electronic power conditioning and control of the production and distribution of electricity are important aspects of the smart grid. In order to get maximum output from a PV and wind energy system, an extensive research has been underway for long time so as to access the performance of hybrid system. This paper presents $P V$ - wind hybrid system along with maximum power point tracking control algorithms, power electronics converters to control the system, filters to reduce the harmonics from the converters. The proposed model and its control strategy offer a proper tool for smart grid performance optimization. The proposed hybrid system is experimentally verified in Matlab/Simulink.

KEY WORDS: Power Management, Wind, Solar System, Cuckoo Technique and Sliding Mode.

Copyright (C) 2020 International Journal for Modern Trends in Science and Technology

DOI: https://doi.org/10.46501/IJMTST060723

\section{INTRODUCTION}

Increased utilization of renewable energy into power grid gave birth to several challenges those are experienced in integrating such sources amongst themselves as well as with the grid. Though the energy obtained from such sources is environment friendly, the power and voltage obtained from such sources varies randomly with the variation of weather. Furthermore, non-linear power converters, used for conditioning the outputs from such sources, distorts the waveform and hence degrades the quality of dispatched power thereby affecting sensitive loads connected to the grid [1]. Exhaustion of fossil fuels, their hazardous effect on environment and an increasing power demand results in an increased utilization of renewable energy sources into the utility grid. Li-ion batteries though costly have higher power density and can withstand higher charging/discharging cycles than lead-acid batteries while NiMH batteries are costlier and have carcinogenic effects on the atmosphere in spite of having higher power density than Li-ion batteries [2]. LCPV collectors used in this work have a degree of concentration of $2.2 \mathrm{X}$ which does not require any extra tracking mechanism and cooling arrangements for their cells.

This paper presents a complete hybrid system which comprising of wind turbines, PV, FC, 
electrolyzer, and battery storage system. In this paper, the Wind and solar systems acts as a primary generating systems which to fulfill the advantages of non-conventional sources, and therefore the Fuel Cell based electrolyzer combination is utilized in this paper for backup device.

\section{Configuration of Proposed Hybrid System}

The operational diagram for proposed stand-alone hybrid system is shown in figure 1 . This technique is thought-about as an entire "green" power generation system as a result of the most energy sources and storage system square measure all environmentally friendly. Once there's excess wind and/or solar generation offered, the electrolyzer activates to start manufacturing $\mathrm{H}$ that is delivered to the $\mathrm{H}$ storage tanks [3].

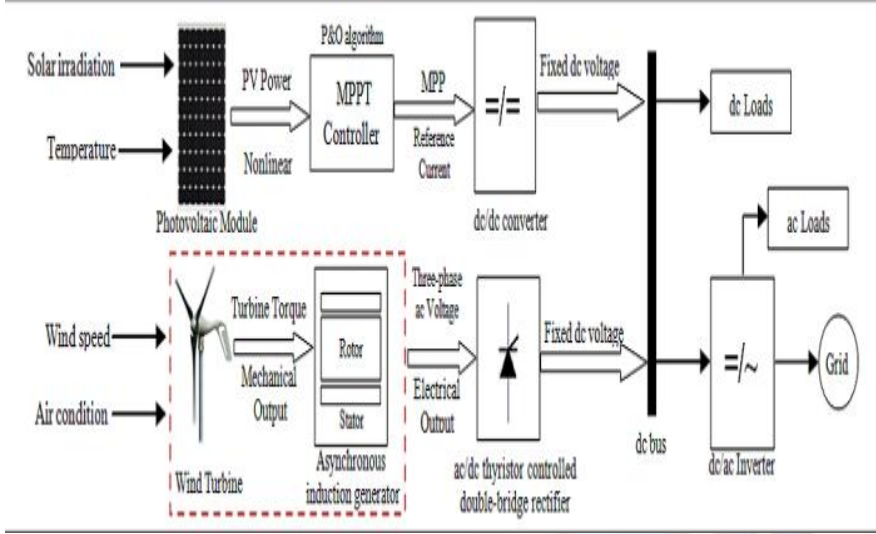

Fig 1: Basic architecture of Hybrid System

\section{PV GENERATION SYSTEM:}

In electrical wonder (PV) framework, photovoltaic cell is that the essential component. PV exhibit is nothing however solar cells zone unit associated nonparallel or parallel for increasing required current, voltage and high power. It delivers the streams once light-weight ingested at the intersection, by the electrical wonder result. Figure three shows at a protection yield power trademark bends for the PV exhibit [4]. It is seen that a most divider attachment exists on each yield power trademark capacity. The Figure three demonstrates the $(\mathrm{I}-\mathrm{V})$ and $(\mathrm{P}-\mathrm{V})$ attributes of the $\mathrm{PV}$ cluster at very surprising star intensities.

The analysis of current expression from PV system is expressed as:

$$
\begin{aligned}
& \mathrm{I}=\mathrm{Iph}-\mathrm{ID}-\mathrm{Ish} \\
& \mathrm{I}=\mathrm{Iph}-\mathrm{Io}[\exp (\mathrm{q} \mathrm{VD} / \mathrm{nKT})]-(\mathrm{VD} / \mathrm{RS})
\end{aligned}
$$

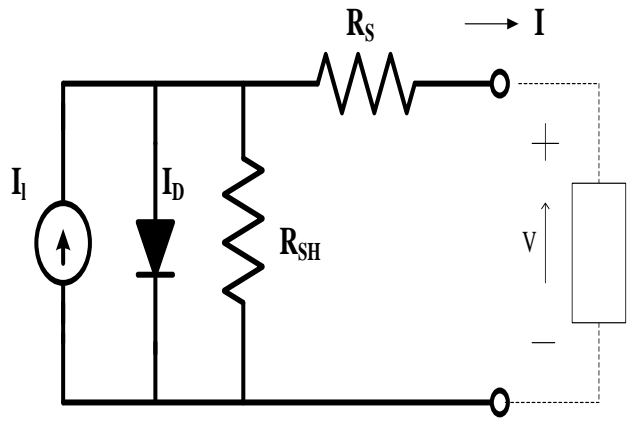

Figure 2: PV module Electrical Circuit

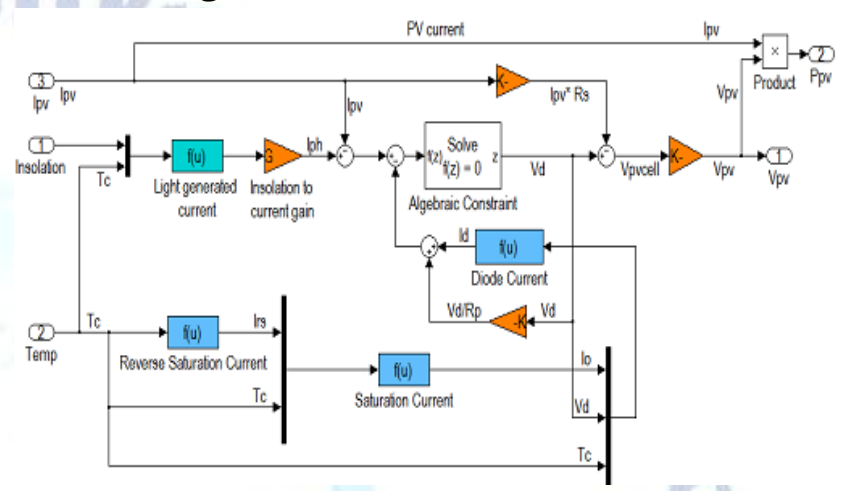

Figure 3: Control Diagram for PV System Figure 3 shows the Solar panel I-V characteristics with constant temperature and irradiance.
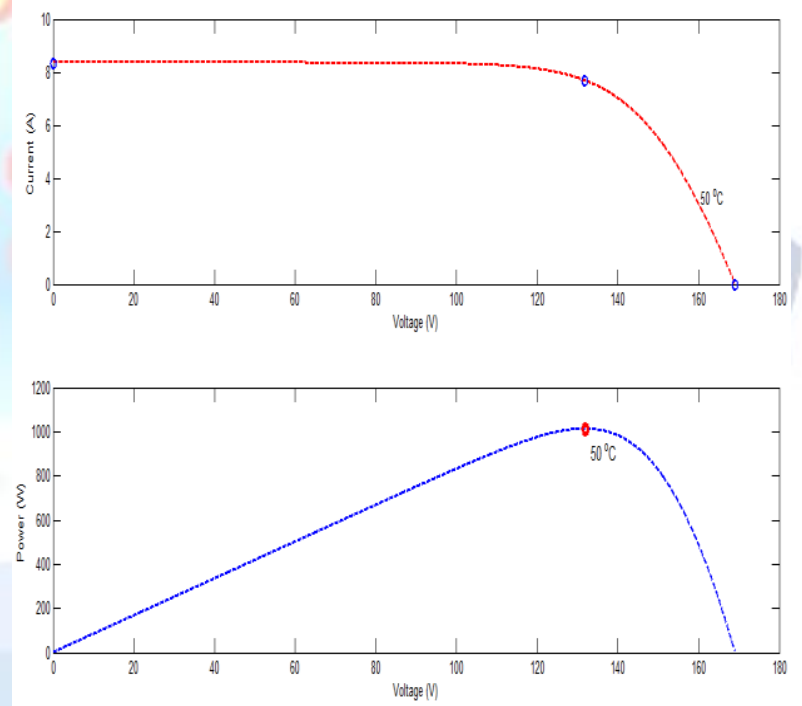

Figure 3: V-I Characterestics of PV system

\section{Cuckoo MPPT Algorithm}

Due to its sound and aggressive reproduction strategies cuckoos are fascinating birds. Generally, cuckoo birds lay their eggs in communal nests and may remove others eggs to increasing hatching probability of their own eggs. Female cuckoos search and select a group of host spices with similar nest sites and egg characteristics to their own, then choosing the best from these nests [8].

Cuckoo birds start in looking for the best nest, and this is important step has an important role in cuckoo's reproduction method. To search 
for best nest and process of food, the Le'vy flight plays a key role. This type of behaviour is used in making optimization for different problems [9]. The step length or Le'vy flight distribution is shown in equation (4).

$$
S=\alpha_{q}\left(V_{b t}-v_{j}\right) \oplus l e(\lambda)
$$

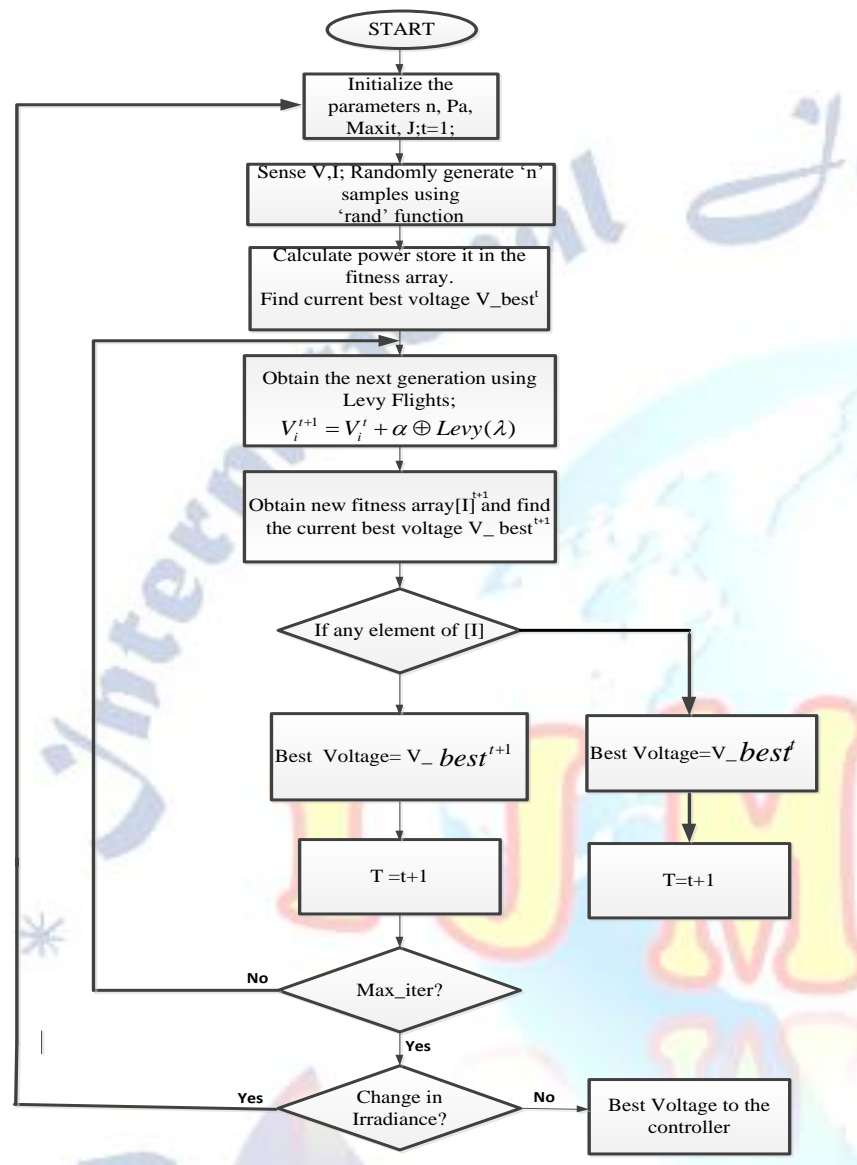

Figure 4: Cuckoo Search Algorithm

Figure 4, shows the flowchart for Le'vy based cuckoo search algorithm [9]. In this the random initial solution of the operating voltage and current of PV panel is selected. The fittness of power is calculated as shown $\mathrm{P}=\mathrm{V}^{*} \mathrm{I}$.

Then find the best current, choose a random nest and generate a new solution by random walks as shown in equation (5).

$$
V_{i}^{t+1}=V_{i}^{t}+\alpha \oplus \operatorname{levy}(\lambda)
$$

\section{WIND TURBINE:}

Wind turbines square measure classified into 2 general types: Horizontal axis wind turbine and Vertical axis wind turbine. A vertical axis wind machine has its blades rotating on axis perpendicular to the bottom. The square measure variety of obtainable styles for each and every kind has bound benefits and downsides [7].

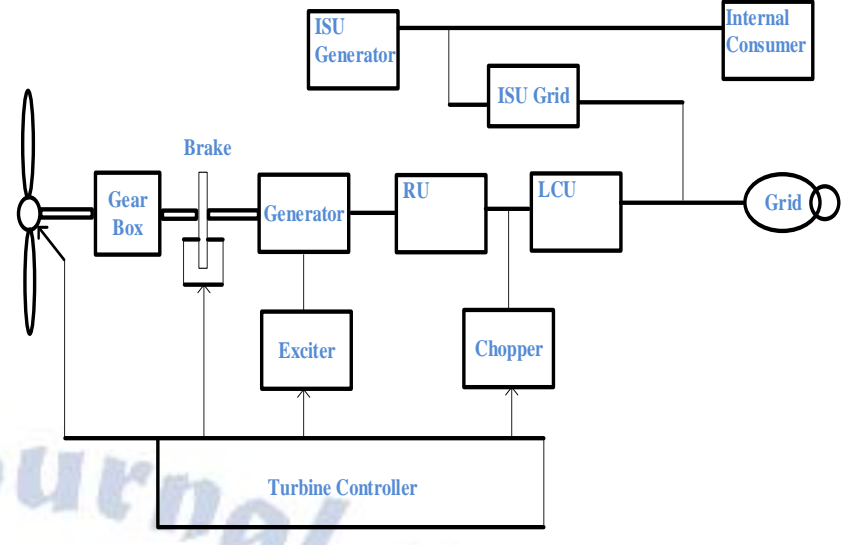

Figure 5: Basic Wind Turbine System

The wind turbines with a squirrel cage generator are equipped with a soft starter mechanism for reactive power compensation as coop generators consume reactive power. This generator and also the turbine rotor area unit coupled through a shell, because the best rotor and generator speed ranges are totally different.

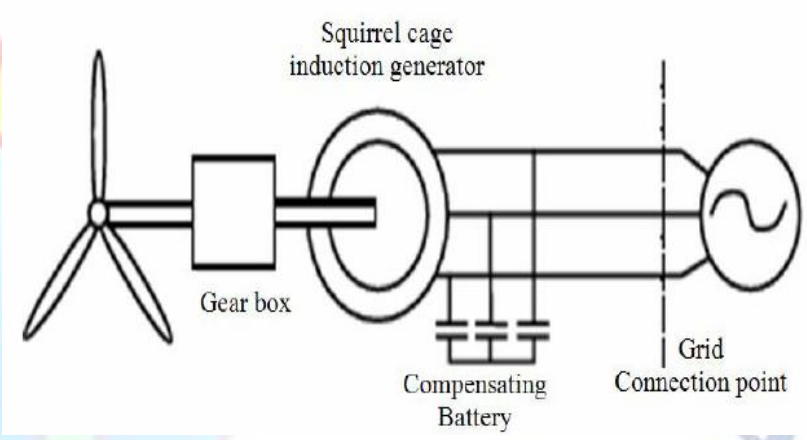

Figure 6: SCIG based WES

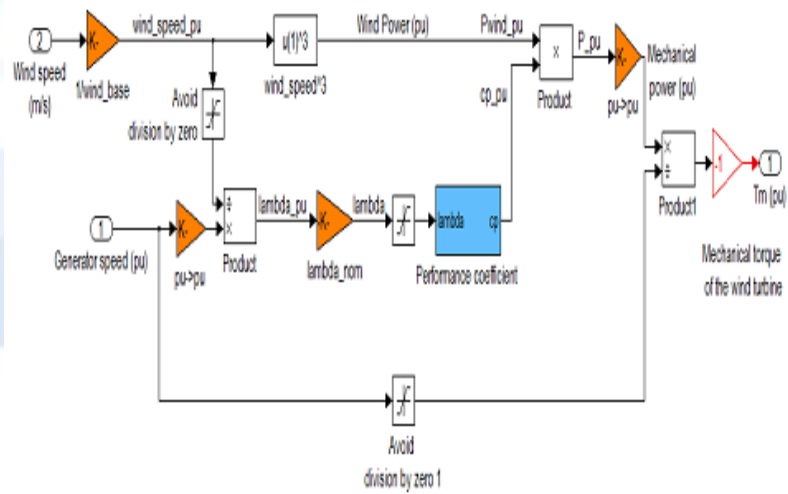

Figure 7: Implementation of Wind Turbine

\section{Control Structure:} System

Figure 8 shows the complete control strategy of hybrid system for effective power management strategy. In this, the wind energy is generally controlled using pitch angle controller and an MPPT technique for controlling Photovoltaic system [1] [14]. The power balancing equation for total hybrid system is expressed below, 


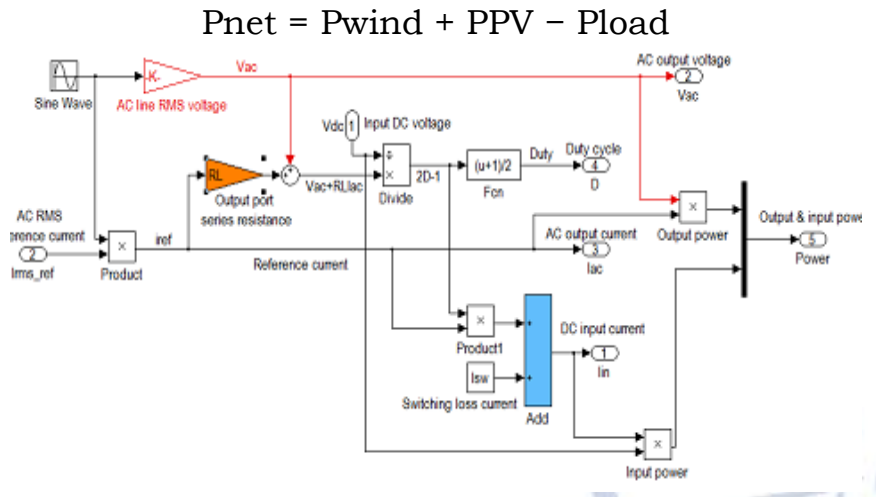

Figure 8: Control Diagram for Power management strategy in Hybrid System

\section{SIMULATION DIAGRAM AND RESULTS}

The simulation can be done based on figure 1. The experimental verification for proposed grid based hybrid unit is done under two cases based on the weather conditions of solar system.

In this the solar system and wind system is designed as per the modelling expressions presented in the previous sections. The solar plant is designed to generate $16 \mathrm{kw}$ and Wind energy system is designed to generate $20 \mathrm{kw}$. The power management strategy for different load conditions is shown.

The following system is tested and verified under three different load conditions such as,

Case 1: Proposed Hybrid system with Power Management Strategy using PO based MPPT technique.

Case 2: Proposed Hybrid system with Power Management Strategy using Cuckoo based MPPT technique.

Case 1: Proposed Hybrid system with Power Management Strategy using PO based MPPT technique.
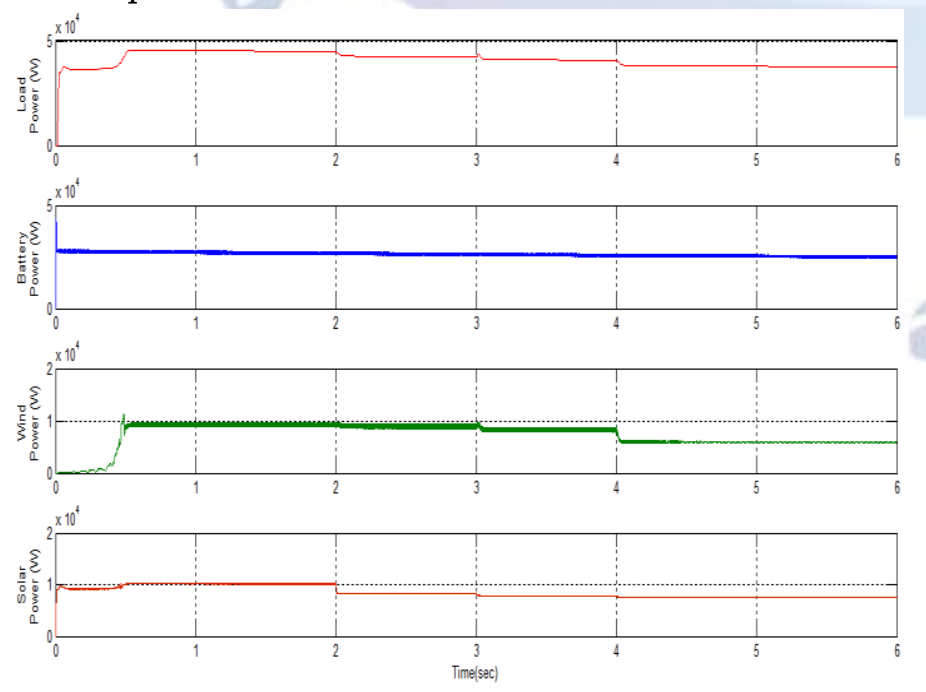

146 International Journal for Modern Trends in Science and Technology
Figure 9: Simulation Result for (a) Load Demand, (b) Solar Power, (c) Grid Power and (d) Battery Power

Figure 9 shows the simulation result for the proposed system to show the power management strategies. Here, the load sharing is chosen between PV, battery and wind system according to their generations. The solar system generates $10 \mathrm{~kW}$ during $0 \mathrm{~s}$ to $2 \mathrm{~s}$ and $8 \mathrm{kw}$ between $2 \mathrm{~s}$ to $6 \mathrm{~s}$. And the wind system generates $9.8 \mathrm{~kW}$ between $0 \mathrm{~s}$ to $4 \mathrm{~s}$ and $6 \mathrm{~kW}$ during $4 \mathrm{~s}$ to $6 \mathrm{~s}$. The demand for load to this system is approximately $47 \mathrm{~kW}$ and it is changed to $38 \mathrm{~kW}$ during the period $3 \mathrm{~s}$ to $6 \mathrm{~s}$.

Case 2: Proposed Hybrid system with Power Management Strategy using Cuckoo based MPPT technique.
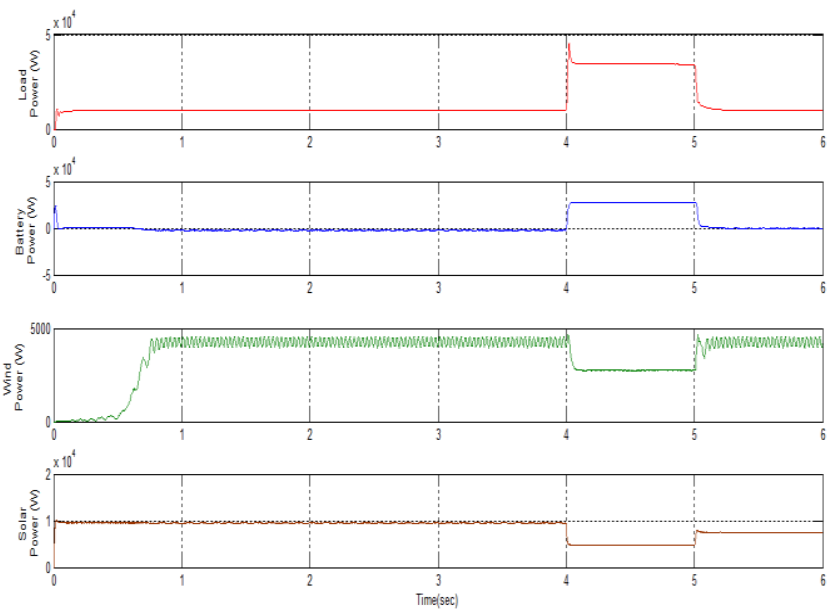

Figure 10: Simulation Result for (a) Load Demand, (b) Solar Power, (c) Wind Power and (d) Battery Power using Cuckoo Technique

Figure 10 shows the simulation result for the proposed system to show the power management strategies implemented with PO MPPT controller. Here, the load sharing is chosen between PV, battery and grid system according to their generations. The irradiance to solar system is considered in variable mode i.e during 0 s to $4 \mathrm{~s}$ the irradiance is $1000 \mathrm{w} / \mathrm{m} 2,800 \mathrm{w} / \mathrm{m} 2$ applied during $4 \mathrm{~s}$ to $5 \mathrm{~s}$ and later it changed to $900 \mathrm{w} / \mathrm{m} 2$. Based on these conditions, the output from the solar system like $10 \mathrm{~kW}$ during $0 \mathrm{~s}$ to $4 \mathrm{~s}$ and $8.2 \mathrm{kw}$ between $4 \mathrm{~s}$ to $5 \mathrm{~s}$ and again it raised to $9 \mathrm{~kW}$ after $5 \mathrm{~s}$. The wind energy system generates $4.8 \mathrm{~kW}$ between $0 \mathrm{~s}$ to $4 \mathrm{~s}$ with wind speed of $9 \mathrm{~m} / \mathrm{s}$, it generates $3.6 \mathrm{~kW}$ during $4 \mathrm{~s}$ to $5 \mathrm{~s}$ with wind speed of $7 \mathrm{~m} / \mathrm{s}$ again after $5 \mathrm{~s}$ the wind speed is changed to $9 \mathrm{~m} / \mathrm{s}$ and generates $4.8 \mathrm{~kW}$. The demand for load to this system is approximately $14 \mathrm{~kW}$ and it is changed to $45 \mathrm{~kW}$ during the period $4 \mathrm{~s}$ to $5 \mathrm{~s}$. The $\mathrm{PV}$ and Wind system contributes their generation 
to meet the load requirement and the excess requirement is taken from battery system or gives to the battery if generation is more than demand.

\section{v. CONCLUSION}

In this paper, a novel PV/WT hybrid power system is designed and modelled for smart grid applications. The developed algorithm comprises system components and an appropriate power flow controller. The model has been implemented using the MATLAB/SIMULINK software package, and designed with a dialog box like those used in the SIMULINK block libraries. The available power from the PV system is highly dependent on solar radiation. To overcome this deficiency of the PV system, the PV module was integrated with the wind turbine system. And also a Cuckoo based MPPT techniques were proposed for both PV \& Wind in order to improve the system performance. The dynamic behavior of the proposed model is examined under different operating conditions.

\section{REFERENCES}

[1] Global Wind 2007 report, Global Wind Energy Council. [Online]. Available: http://www.gwec.net/index.php?id=90

[2] Wind Power Today-Federal Wind Program Highlights. NREL, DOE/GO- 102005-2115, Apr. 2005.

[3] Trends in Photovoltaic Applications: Survey Report of Selected IEA Countries between 1992 and 2004, International Energy Agency Photovoltaics Power Systems Programme (IEA PVPS), Sep. 2005.

[4] K. Agbossou, M. Kolhe, J. Hamelin, and T. K. Bose, "Performance of a stand-alone renewable energy system based on energy storage as hydrogen," IEEE Trans. Energy Convers., vol. 19, no. 3, pp. 633-640, Sep. 2004.

[5] D. B. Nelson, M. H. Nehrir, and C. Wang, "Unit sizing and cost analysis of stand-alone hybrid Wind/PV/fuel cell systems," Renewable Energy, vol. 31, no. 10, pp. 1641-1656, Aug. 2006.

[6] R. Lasseter, "Dynamic models for micro-turbines and fuel cells," in Proc. 2001 PES Summer Meet., vol. 2, pp. 761-766.

[7] Y. Zhu and K. Tom sovic, "Development of models for analyzing the load following performance of micro turbines and fuel cells," J. Electric Power Syst. Res., vol. 62, pp. 1-11, 2002.

[8] S. H. Chan, H. K. Ho, and Y. Tian, "Multi-level modeling of SOFC-gas turbine hybrid system," Int. J. Hydrogen Energy, vol. 28, no. 8, pp. 889-900, Aug. 2003.

[9] H. Dehbonei, "Power conditioning for distributed renewable energy generation," Ph.D. dissertation, Curtin Univ. Technol., Perth, W.A., Australia, 2003.

[10] P. A. Lehman, C. E.Chamberlin, G. Pauletto, and M. A. Rocheleau, "Operating experience with a photovoltaic-hydrogen energy system," presented at the Hydrogen 1994: 10thWorld Hydrogen Energy Conf., Cocoa Beach, FL, Jun.

[11] A. Arkin and J. J. Duffy, "Modeling of PV, electrolyzer, and gas storage in a stand-alone solar-fuel cell system," in Proc. 2001 Nat. Solar Energy Conf., Annu. Meet, Am. Solar Energy Soc., Washington, DC.
[12] L. A. Torres, F. J. Rodriguez, and P. J. Sebastian, "Simulation of a solar hydrogen- fuel cell system: Results for different locations in Mexico," Int. J. Hydrogen Energy, vol. 23, no. 11, pp. 1005-1010, Nov. 1998.

[13] S. R. Vosen and J. O. Keller, "Hybrid energy storage systems for standalone electric power systems: Optimization of system performance and cost through control strategies," Int. J. Hydrogen Energy, vol. 24, no. 12, pp. 1139-1156, Dec. 1999.

[14] Th. F. El-Shatter, M. N. Eskandar, and M. T. El-Hagry, "Hybrid PV/fuel cell system design and simulation," Renewable Energy, vol. 27, no. 3, pp. 479-485, Nov. 2002.

[15] T. Azib, R. Talj, O. Bethoux "Sliding Mode Control and Simulation of a Hybrid Fuel-Cell Ultra capacitor Power System", 978-1-4244-6392-3/10/\$26.00 (2010 IEEE.

[16] "Improvement of power quality using fuzzy logic controller in grid connected photovoltaic cell using UPQC" Ramalingeswara Rao .K, Srikanth .K.S, International Journal of Power Electronics and Drive Systems 2014.

[17] "A three phase multi-level converter for grid connected PV system" Srikanth.K.S, International Journal of Power Electronics and Drive Systems 2014.

[18] "Improvement of power quality for microgrid using fuzzy based UPQC controller" Srikanth .K.S, Mohan .T.K, Vishnuvardhan.P, International Conference on Electrical, Electronics, Signals, Communication and Optimization, EESCO 2015.

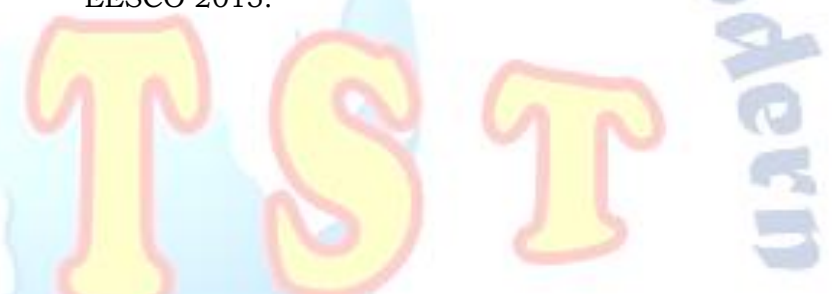

